\title{
Oroantral fistulas closure using Bichat's fat pad
}

\author{
Fechamento de fístulas bucossinusais através do uso da bola de Bichat
}

\author{
Marcelo Fernando do AMARAL \\ Luiz Antonio Portela GUERRA² \\ Marleny Elizabeth Márquez de Martínez GERB| ${ }^{3}$ \\ Audemir Rocha MELO' \\ David Gomes de Alencar GONDIM ${ }^{1}$ \\ RUi MEDEIROS JUNIOR ${ }^{1}$ \\ Suzana Lubambo de MELO3 \\ Alexandrino Pereira dos SANTOS NETO3
}

\begin{abstract}
The oroantral fistula is one of the complications most common after dental extractions in posterior maxillary, mainly in the region of second and third molar. The diagnosis is based on clinical signs and symptoms, which may be present in pain, fever, hyposmia and drainage of purulent discharge; additional examinations such as computed tomography and sinus nasal endoscopy improve diagnostic precision. It is therefore of paramount importance to correct early diagnosis and treatment avoiding in this way, the symptons of sinusitis, infections and dysphonia. Several surgical techniques have been proposed for the closure of the bucosinusal fistula; the use of Bichat's fat pad has become a successful alternative among them. Many surgical treatments have been to propose for closure of bucosinusal fistula; Bichat fat pad has been a good alternative. The propose for this article is report two cases with closure of bucosinusal fistulas through Bichat's fat pad, as well as to discuss the surgical techniques, characteristics, indications and peculiarities.
\end{abstract}

Indexing terms: Oroantral fistula. Oral surgical procedures. Surgical flaps.

\section{RESUMO}

A fístula bucosinusal ou oro-antral é uma das complicações mais comuns, após extrações dentárias na região posterior de maxila, principalmente em região de segundo e terceiro molares permanentes. O diagnóstico se baseia em sinais e sintomas clínicos, nos quais pode-se destacar: dor, febre, hiposmia e drenagem de secreção purulenta. Os exames complementares como a endoscopia sinonasal e a tomografia computadorizadá melhoram a precisão diagnóstica. Assim, é de suma importância, o correto diagnóstico e tratamento precoce, evitando dessa maneira a instalação de sinusites, infecções e disfonia. Diversas técnicas cirúrgicas têm sido propostas na literatura, para o fechamento da fístula bucossinusal, dentre elas, a utilização do corpo adiposo de Bichat tem se tornado uma alternativa bem sucedida. O objetivo deste trabalho é relatar dois casos clínicos de fechamento de fístulas bucossinusais através do retalho da bola de Bichat, realizados pelo Departamento de Cirurgia e Traumatologia Bucomaxilofacial do Hospital da Face e Hospital da Restauração em Recife, Pernambuco. Ainda, descrever acerca de sua técnica cirúrgica, características, indicações e peculiaridades.

Termos de indexação: Fistula bucoantral. Procedimentos cirúrgicos bucais. Retalhos cirúrgicos.

\section{INTRODUCCION}

Maxillary sinuses are spaces filled with air, located bilaterally in the maxilla. These are lined by a respiratory epithelium, secreting mucus and these are the largest among the paranasal sinuses ${ }^{1}$. An oroantral communication generally occurs for some reason after dental extractions; and, it creates a way among the maxillary sinus and the oral cavity that due to tissue proliferation. Both from sinus and oral mucosa develop an epithelialised way (fistula) among the cavities².

Communications generally are results from dental extractions with divergent roots near edentulous spaces, situation in which maxillary sinus becomes pneumatized, decreasing the alveoli and carrying the tooth apex to a very straight conexion with the sinus cavity ${ }^{3}$. The proximity of the root apices to the sinus cavity makes more susceptible the dental element extraction to occur oroantral communication and it is being obeyed by the following decreasing order related to the risk: second molar, first molar, third molar, second premolar and first premolar ${ }^{4}$. Cystic and tumor lesion as well as local traumas are also found as etiological factors for such occurrence.

Several methods have been proposed in the literature for oral sinus communication closures such as local flaps, remote flaps, grafting and the adipose tissue of the cheek. Among the mucoperiosteal flaps from the labial area which is described by Rehrmann as the most used

\footnotetext{
1 Hospital da Restauração, Residência em Cirurgia e Traumatologia Buco-Maxilo-Facial. Recife, PE, Brasil.

2 Universidade de Pernambuco, Faculdade de Odontologia, Departamento de Cirurgia e Traumatologia Buco-Maxilo-Facial. Camaragibe, PE, Brasil.

3 Universidade de Pernambuco, Faculdade de Odontologia. Av. General Newton Cavalcanti, 1650, Tabatinga, 54753-901, Camaragibe, PE, Brasil.

Correspondência para / Correspondence to: MEMM GERBI. E-mail: <marleny_gerbi@msn.com>.
} 
because it has a broad base. The blood supply of the flap is guaranteed and the mobility of itself can be improved through the performance of incisions in the periosteum at flap base. The palatal flaps are designed based on the largest palatal vessels and these are classified as rotational flaps. This type of flap has good mobility and thickness of tissue $e^{5-6}$. The closure of oroantral fistula can yet be done through the use of monocortical bone grafts or tooth transplant?

The adipose tissue of the cheek was used by Abuabara et al. ${ }^{6}$ for closure of oroantral fistula in 28 patients, obtaining success index of $100 \%$ in the cases.

The objective of this paper is to report two clinical cases of oroantral fistula closure through Bichat fat pad as well as to describe about it surgical technique, characteristics, indication and peculiarities.

\section{CASE REPORT}

\section{Clinical case 1}

Patient, 47 years, female, sought the Oral and Maxillofacial Traumatology Surgical Service in the 'Hospital da Face' (Recife-PE), complaining of liquid outflow through nasal cavity by feeding himself. About the clinical intra-oral examination, it was observed opening on the superior second molar (Figure 1) and the maxilla showed up edentulous.

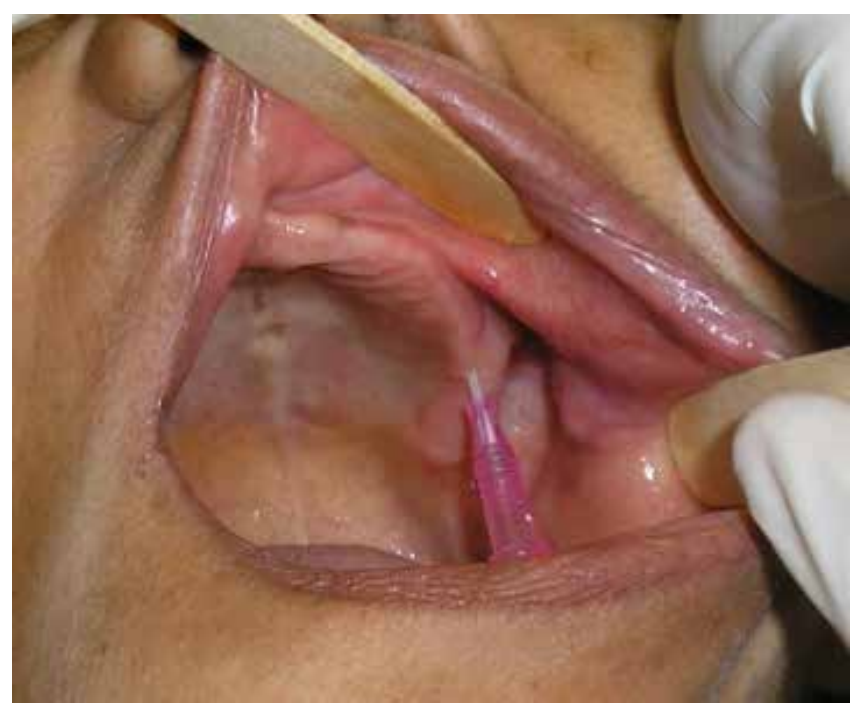

Figure 1. Clinical aspect: introduction of a catheter to identify a communication

Patient reported dental extraction in that region for the past 12 months and not complaining about pain. The curse of sinusitis disappeared after following a clinical and image examination. The treatment proposed was the oroantral fistula closure with Bichat's fat pad.
Local anesthesia initially was given through superior alveolar nerve blocks: previous, intermediate, posterior and major palatine nerve; incision around the fistula subsequently was performed with $n^{\circ} 15$ scalpel blade and excision of this. The cleaning of maxillary sinus was performed with $0,9 \%$ saline solution (SS) and then a quadrangular oral mucoperiosteal flap was made through 0,9\% saline solution irrigation $(100 \mathrm{ml})$ with relaxing incisions, previous and posterior to the fistula, at the level of posterior region, which would be the second molar. Incisions in the periosteum of the flap was made with Bichat fat pad herniation through divulsion and the traction of this was performed to the local of communication. The suture with 4-0 silk thread and the flap reposition to the original repositioning were made (Figure 2). The removal of the suture happened after 15 days of the surgical procedure (Figure 3).The patient authorized the publication of his case after signing written consent form. She was clinical followed-up during 18 months and showed no signs of recurrence of fistula.

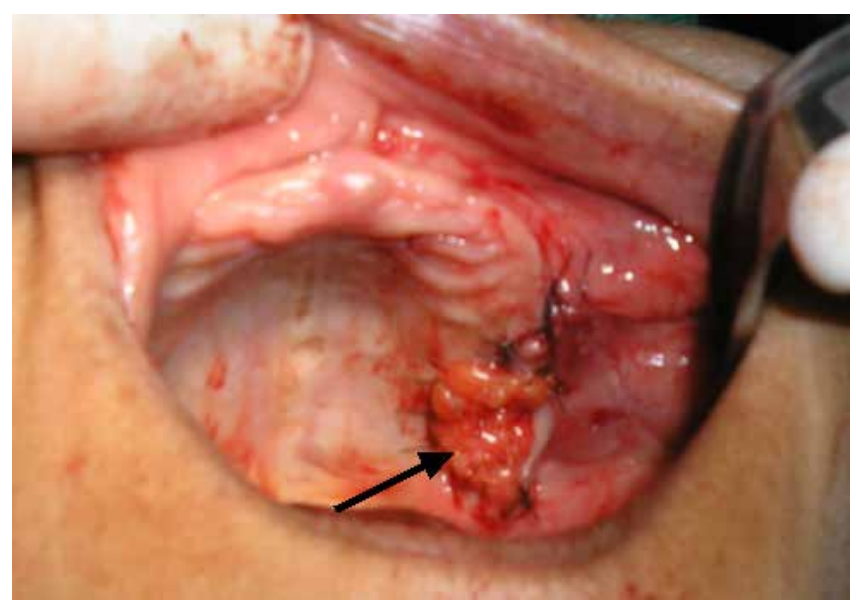

Figure 2. Immediate postoperative period. Observe the arrow pointing to the adipose tissue in position.

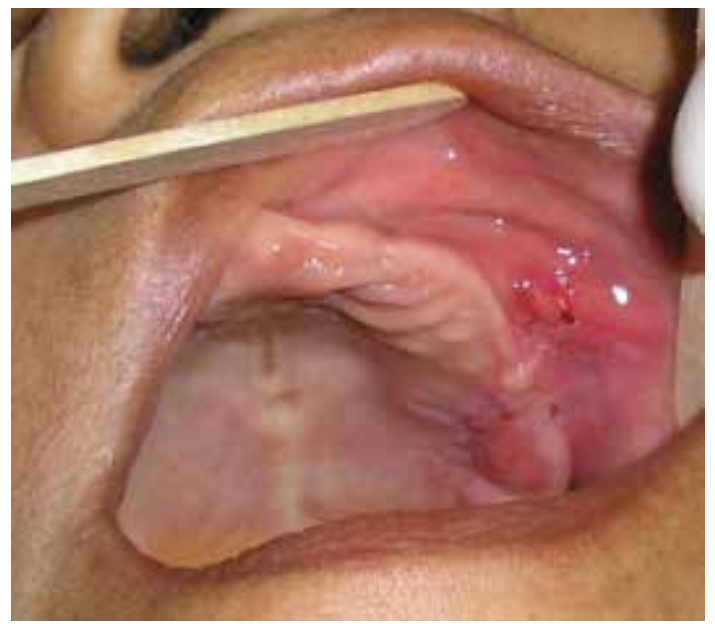

Figure 3. Aspects after 15 days with communication closure. Observe the metaplasia. 


\section{Clinical case 2}

Patient 22 years old, male, attended the Surgery and Oral maxillofacial Traumatology Department at the 'Hospital da Restauração' in Recife (PE). The main complaint was a "hole in the mouth" and water flow by the nostrils during oral hygiene or performance of mouthwashes. During the anamneses the patient related to have done an exodontia of the element 17 for 4 months. There was a fistula in the previous extraction region confirmed by x-ray image (Figure 4) which can be observed solution continuity from the floor of the right maxillary sinus, veiling absence of the maxillary sinus which would suggest chronic sinusitis and element included in the region.

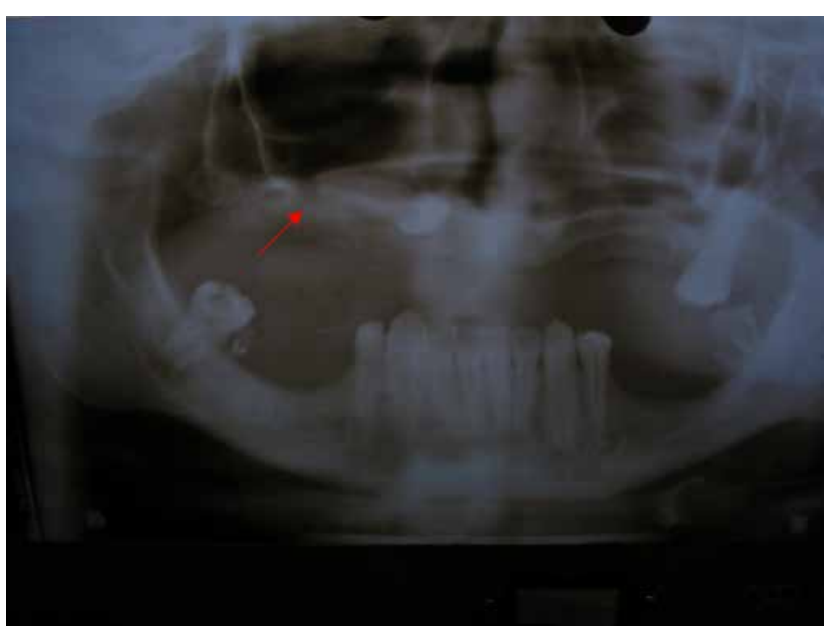

Figure 4. Panoramic radiograph. Observe the Arrow identifying communication and associated element included.

Fistula closure through Bichat's fat pad rotation was proposed and the maintenance of the element was included (Figure 5 and 6).The surgical procedure differentiated itself from the clinical case 1 because it is a triangular mucoperiosteal flap only with an anterior relaxing incision to the fistula. The synthesis was performed with 4-0 nylon thread.

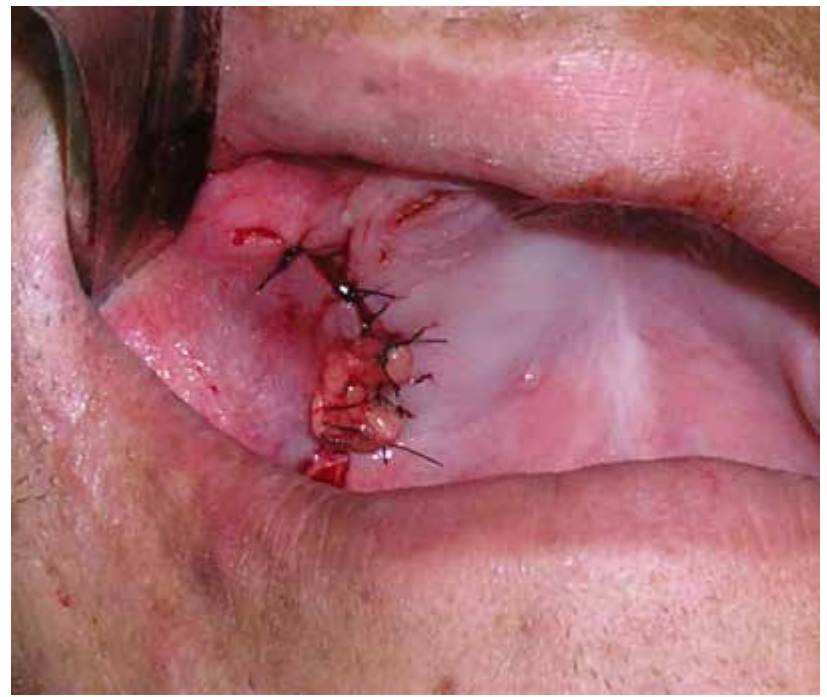

Figure 5. Immediate post-surgical aspect.

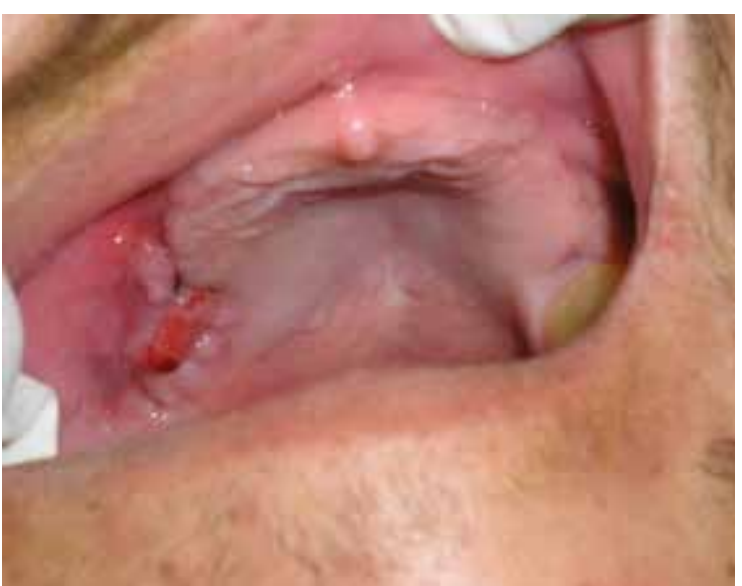

Figure 6. Aspect after 14 postoperative days. Metaplasia are observed in some areas.

The patient authorized the publication of the case upon signature of an informed consent form and is currently in outpatient follow-up for 14 months without signs of recurrence.

\section{DISCUSSION}

Several methods for closure of oroantral communication have been reported in the literature as the palatine and buccal flap ${ }^{8-9}$. However, these methods not always bring significant results.

The Valsalva maneuver is a type of physical evaluation and it is important in the diagnosis of oroantral fistula, however, it might not be used for communication diagnosis soon after dental element extraction because it can cause or increase communication.

The adipose tissue of the cheek was described for the first time in 1802 by Pichat ${ }^{6}$ but only in 1977 Egyedi $^{10}$ used it in oroantral and oronasal communication as a pediculated graft associated to a skin graft. Its use as a free graft was described by Neder ${ }^{11}$ and as a pediculated graft by Tideman et al. ${ }^{12}$. These same scholars observed that the epithelialisation of the graft occurs during 2 or 3 weeks without necessity to cover this with skin grafts.

The Bichat's fat pad anatomically has elongated formation like as an ice cream cone which the Bichat's fat pad is a superficial extremity that separate buccinators and masseter muscle and the cone separates its deep extension that extends to infratemporal fossa, separating pterygoid muscles and serving as cushion to facilitate the muscle movements related to the other ${ }^{13}$.

As advantages of the Bichat's fat pad are cited: it causes less disturbances and scars in the vestibule than a slippage of flaps ${ }^{14}$, allows adjustments after one week ${ }^{15}$ and is considered a simple and speedy procedure ${ }^{16-17}$ 
without removal of tooth or bones; At least, postoperative discomfort to the patient ${ }^{15-17}$, low morbidity, possibility to be associated to other flaps ${ }^{16}$ and it does not lose furrow depth ${ }^{2,15}$. There was not any complication observed in the two cases presented herein. Patients did not report any significant painful symptomatology; however, we did not agree in relation to the maintenance of the furrow depth related to the use of Bichat's fat pad. We observed loss of furrow depth, however to a lesser extent as compared to that observed with the techniques of using vestibular flaps.

The fact that only can be used just once as a main disadvantages ${ }^{18}$, possibility of trismus in the postoperative period, limitation of its use for small and medium defects, possibility of causing esthetic alterations perceived in the speech $^{16}$. There was not any patient presenting trismus, disturbance of speech or significant esthetic alteration in postoperative period in the cases presented.

We believe that in cases of chronic sinusitis might perform previous antibiotic therapy and postponement of surgical treatment until infectious process stabilization. Postsurgical antibiotic therapy(amoxicillin, $500 \mathrm{mg}, 8-8$ hours for 7 days) was performed in the clinical cases described herein, since in any case was presented chronic sinusitis nasal descongestant was also prescribed(Sorine ${ }^{\circledR}$ Drops) 3 times a day for 7 days, analgesic (dipyrone 500mg) for 2 days and mouthrinses of chlorhexidine digluconate $0,12 \%, 2$ time a day for 7 days as collutory. Postoperative recommendations were passed on as: not to sneeze with closed mouth, not

\section{REFERENCES}

1. Peterson L. Cirurgia oral e maxilofacial contemporânea. $3^{\mathrm{a}}$ ed Rio de Janeiro: Guanabara Koogan; 2000.

2. Garcia RR, Rabêlo LRS, Moraes M, Moreira RWF, AlbergariaBarbosa JR. Utilização de enxerto pediculado do corpo adiposo da bochecha no tratamento de comunicações oro-antrais. Rev Port Estomatol Cir Maxilofac. 2000;41:17-24. doi.10.1590/ S1980-65232010000100021

3. Marzola C. Acidentes e complicações da endodontia: profilaxia e tratamento. In: Marzola C. Técnica exodôntica. $2^{a}$ ed. São Paulo: Pancast; 1994. p. 284-9.

4. Faig-Leite H. Topografia dento-alveloar. In: Madeira MC. Anatomia da face: bases anátomo-funcionais para a prática odontológica. 5ª ed. São Paulo: Sarvier; 2004. p. 29-34.

5. Eppley B, Scaroff A. Oro-nasal fistula secondary to maxillary augmentation. Int J Oral Surg. 1984;13(6):535-8. doi:10.1016/ S0300-9785(84)80026-5 blow the nose, avoid passing the tongue on the surgical site, maintain good oral hygiene and mild diet.

We consider that copious irrigation with saline solution( $0,9 \%)$ of the involved maxillary sinus is an important step for a reduced possibility of infection with flap loss and consequently a fistula recurrence.

\section{CONCLUSION}

It concludes that the use of Bichat's fat pad for closure of oroantral fistulas should be included more frequently in the surgical possibilities because it is a procedure relatively simple with low complication index, comfortable postoperative for the patient and it can be used for closure of small and medium defects in the molar region up to the canine.

\section{Collaborators}

MF AMARAL and LAP GUERRA performed surgery for closure of oroantral fistula related to the first clinical case cited and conducted in the 'Hospital da Face' and participated of the paper writing. AR MELO, DGA GONDIM and R MEDEIROS JUNIOR performed surgery for closure of oroantral fistula related to the second clinical case cited and conducted in the 'Hospital da Restauração' and participated of the paper writing MEMM GERBI, SL MELO and AP SANTOS NETO took part of the writing paper.
6. Abuabara A, Cortez AL, Passeri LA, De Moraes M, Moreira RW. Evaluation of different treatments for oroantral/oronasal communications: experience of 112 cases. Int J Oral Maxillofac Surg. 2006;35(2):155-8. doi:10.1016/j.ijom.2005.04.024

7. Haas R, Watzak G, Baron M, Tepper G, Mailath G, Watzek G. A preliminary study of monocortical bone grafts for oroantral fistula closure. Oral Surg Oral Med Oral Pathol Oral Radiol Endod. 2003;96(3):263-6. doi: 10.1016/ S1079210403003755

8. Killey HC, Key LW. An analysis of 250 cases of oro-antral fistula treated by the buccal flap operation. Oral Surg Oral Med Oral Path. 1967; 24(6):726-39. doi:10.1016/0030-4220(67)90506-3

9. Yih WY, Merrill RG, Howerton DW. Secondary closure of oroantral and oronasal fistulas: a modification of existing techniques. J Oral Maxillofac Surg. 1988;46(5):357-64. doi:10.1016/02782391(88)90218-2

10. Egyedi P. Utilization of the buccal fat pad for closure of oroantral and/or oro-nasal communications. J Maxillofac Surg. 1977:5(4):241-4. doi:10.1016/S0301-0503(77)80117-3 
11. Neder A. Use of buccal fat pad for grafts. Oral Surg Oral Med Oral Pathol. 1983;55(4):349-50. doi:10.1016/0030-4220(83)90187-1

12. Tideman $H$, Bosanquet $A$, Scott J. Use of the buccal fat pad as a pedicled graft. J Oral Maxillofac Surg. 1986;44(6):435-40. doi: 10.1016/S0278-2391(86)80007-6

13. Madeira MC. Anatomia da face. São Paulo: Editora Sarvier; 1995.

14. Baumann A, Ewers R. Application of the buccal fat pad in oral reconstruction. J Oral Maxillofac Surg. 2000;58(4):389-92. doi:10.1016/j.ajoms.2011.05.001

15. Hanazawa $Y$, Itoh $K$, Mabashi $T$, Sato $K$. Closure of oroantral communications using a pedicled buccal fat pad graft. J Oral Maxillofac Surg. 1995;53(7):771-5. doi:10.1016/02782391(95)90329-1
16. Dean A, Alamillos F, García-López A, Sánchez J, Penãlba $M$. The bucal fat pad flap in oral reconstruction. Head Neck. 2001;23(5):383-8. doi: 10.1002/hed.1048

17. Martín-Granizo R, Naval L, Costa A, Goizueta C, Rodriguez F, Monje $F$, et al. Use of buccal fat pad to repair intraoral defects: review of 30 cases. Br J Oral Maxillofac Surg. 1997;35(2):81-4. doi:10.1016/S0266-4356(97)90680-X

18. Rapidis AD, Alexandridis CA, Eleftheriadis E, Angelopoulos AP The use of the buccal fat pad for reconstruction of oral defects: review of the literature and report of 15 cases. J Oral Maxillofac Surg. 2000;58(2):158-63. doi:10.1016/S0278-2391(00)90330-6

Received on: 8/7/2011 Final version resubmitted on: 9/9/2011 Approved on: 3/10/2012 
